\title{
Parasite communities of four fish species in the Wadden Sea and the role of fish discarded by the shrimp fisheries in parasite transmission
}

\author{
S. Groenewold ${ }^{1}$, R. Berghahn ${ }^{2,3} \&$ C.-D. Zander ${ }^{1}$ \\ ${ }^{1}$ Zoologisches Institut und Zoologisches Museum, Universität Hamburg; Martin-Luther- \\ King-Platz 3, D-20146 Hamburg, Germany \\ ${ }^{2}$ Institut für Hydrobiologie und Fischereiwissenschaft, Elbelabor; Große Elbstraße 268, \\ D-22767 Hamburg, Germany \\ ${ }^{3}$ Umweltbundesamt, Institut für Wasser-, Boden- und Lufthygiene; \\ Schichauweg 58, D-12307 Berlin, Germany*
}

Manuscript received on 2nd February 1994; accepted for publication on 24th June 1994

\begin{abstract}
Parasites were observed in medium- and small-sized fish taken from the discards of a commercial shrimper during seven different cruises in the tidal channels of the North Frisian Wadden Sea (Süderaue, North Sea) from April to September 1991. In total, 442 fish comprising four species (Sprattus sprattus, Hyperoplus lanceolatus, Ammodytes tobianus, Pomatoschistus minutus) were investigated. The parasite fauna consisted of 22 species. The parasite community structure of the 4 hosts was compared. The diet of the hosts seemed to be the main factor determining the structure of the parasite community. Other factors could not be assessed. Eight species of parasites occurred as larval stages. This indicated that fish were intermediate or paratenic hosts in their life cycle. The nematode Hysterothylacium sp. (Anisakidae) and the digenean Cryptocotyle lingua (Heterophyidea) were the dominant parasites, reaching their highest prevalence and density in sprat and sand eel. Sprat and sand eel play a very important role in parasite transmission to predacious fish and seabirds.
\end{abstract}

\section{INTRODUCTION}

Publications on fish parasites in the North Sea are numerous, but to date have mainly dealt with single species (taxa) of parasites or with hosts which are relevant to fisheries, such as flatfish or gadoids (Køie, 1983, 1984; for references see Möller \& Anders, 1986). This paper focusses on parasites of medium- and small-sized fish species, which so far have not been paid much attention, i.e. goby [Pomatoschistus minutus (Pallas, 1770)], sand eel [Ammodytes tobianus Linnaeus, 1758 and Hyperoplus lanceolatus (Le Sauvage, 1824)] and sprat [Sprattus sprattus (Linnaeus, 1758)]. These species play an important role in the food web of the coastal areas of the North Sea (Hartwig \& Söhl, 1975; Kühl \& Kuipers, 1978; Bailey \& Bakken, 1990). They may be of importance for parasites that infest several different components of marine food chains in their life cycle. This is the case for a number of helminth species. Relationships of this kind have been studied in detail in the Baltic Sea (Zander, 1988; Zander \& Döring, 1989, Zander et al., 1993) and in

\footnotetext{
- Present address of second author, addressee for all correspondence.
} 


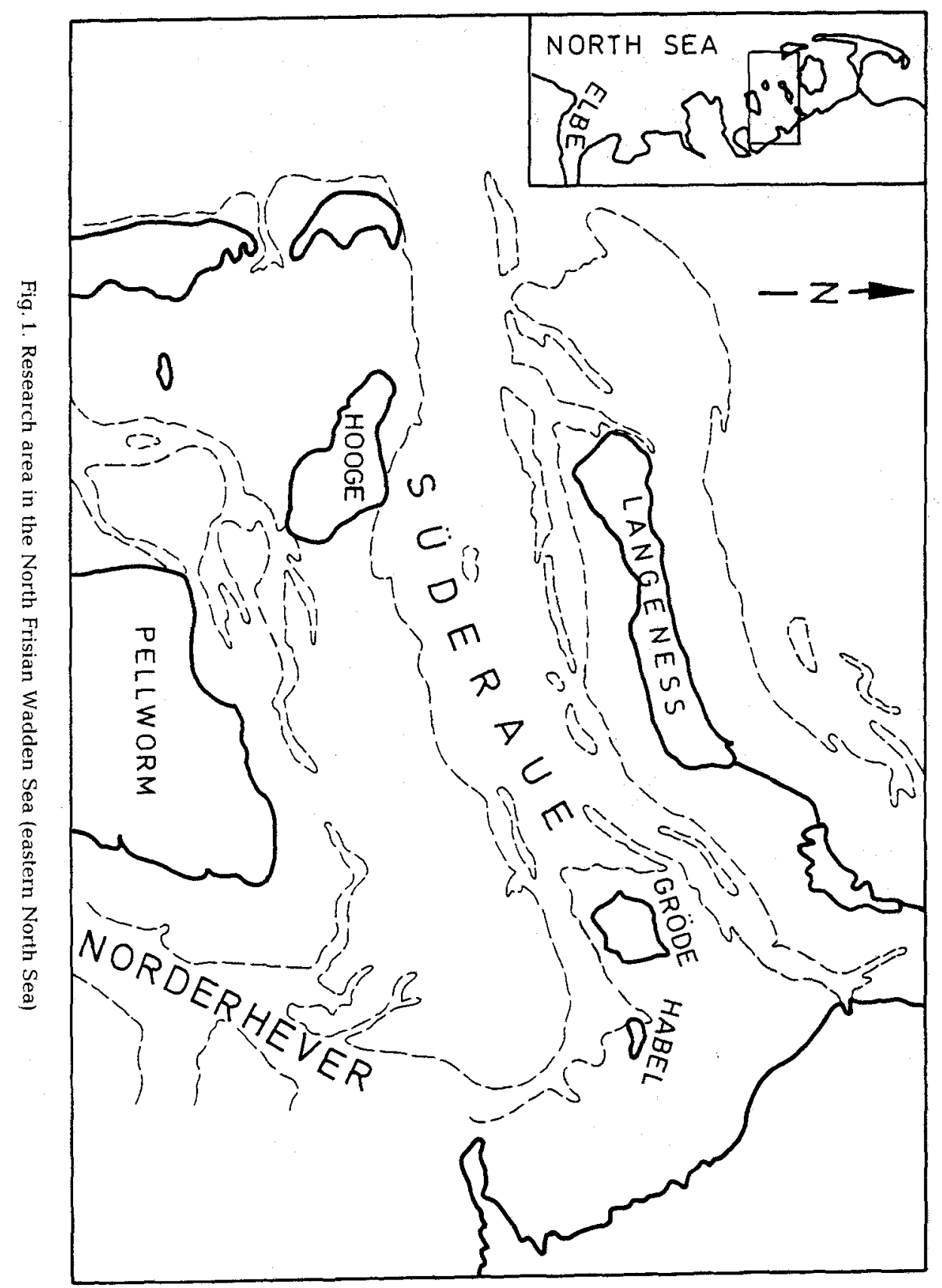


the Schlei fjord (Zander \& Westphal, 1991). In the North Sea, the parasite fauna of gobies (Hamerlynck et al., 1989) and of sprat (Reimer, pers. comm.) have been investigated. Reports on parasites of sand eels in the North Sea are rare (Sprehn, 1960).

The objectives of this study are: (1) to contribute to the inventory of the parasite fauna of the above-mentioned hosts, including the analysis of the community structure; (2) to assess the four fish species as intermediate hosts for parasites that infest a number of final hosts.

The overlapping parasite fauna of the fish species was also studied with regard to similarities in habitat structure of the hosts as well as their role in the food web and differences in autecology. The discards of fishing vessels provide an important food resource for seabirds (Furness, 1987; Berghahn \& Rösner, 1992). Fisheries might thereby promote a number of parasite species to completion of their life cycles in shorter time periods, i.e. in higher numbers or in other words, in higher densities as compared to pristine conditions. Particular attention was paid to the role of medium- and small-sized fish as intermediate hosts for helminths, which have to reach top predators such as fish, sea mammals, and seabirds.

\section{STUDY AREA AND METHODS}

Fish samples were taken from the by-catch of a commercial shrimper during seven different day cruises in the subtidal area "Süderaue" between the islands Langeness, Oland, Gröde, and Hooge (Fig. 1) from April to September 1991. The vessel was equipped with two commercial beam trawls (widths $7.8 \mathrm{~m}$ ); rollers were attached to the ground rope; mesh sizes in the cod end were $11 \mathrm{~mm}$. In total, 442 fish comprising four species were randomly selected from the by-catch: Sprattus sprattus, Ammodytes tobianus, Hyperoplus lanceolatus, Pomatoschistus minutus. Most specimens were fixed in buffered seawater formalin $(5 \%)$. Food organisms from their stomach contents were determined and were subjected to frequency analyses (\% of specimens of a fish species containing these food items) in order to identify potential intermediate hosts. All helminths were transferred to an alcohol-glycerol mixture (Reichenow et al., 1969). Small nematodes and Digenea were placed in glycerol prior to examination under a light microscope; larger specimens of anisakids were cleared in $100 \%$ lactic acid (Berland, 1961; Hartwich, 1975). Anisakid larvae were determined to the genus level according to Berland (1989). Infested organs were defined as "microhabitats" after Rohde (1982).

Besides prevalence [\%] (Rohde, 1982), parasitic burden (all parasites per examined hosts) and abundance (parasites of species " $i$ " per examined hosts of species " $h$ "), the following indices were used:

(1) Relative frequency [\%]:

$$
\text { Relative frequency }=\frac{\mathrm{n}_{\mathrm{i}} \cdot 100}{\mathrm{n}_{\mathrm{all}}}
$$

$\left(\mathrm{n}_{\mathrm{i}}=\right.$ number of parasite individuals of species " $\mathrm{i}$ "; $\mathrm{n}_{\mathrm{all}}=$ number of all parasite individuals of a host species)

(2) Shannon-Wiener-Index:

$$
H s=-\sum_{i=1}^{s}\left(p_{i} \cdot \ln p_{i}\right)
$$


(Hs $=$ diversity index $; p_{i}=$ relative frequency of species " $\mathrm{i}^{\prime \prime}, \mathrm{s}=$ number of species in the community)

(3) Eveness (Streit, 1980):

$$
E=H s / l n S
$$

( $\mathrm{S}=$ number of species of the community)

Prevalence [\%] and relative frequency [\%] (dominance) were subjected to similarity analysis according to Renkonen in order to compare the parasite fauna of host species:

(4) $\mathrm{RI}[\%]=\mathrm{pr}_{1}+\mathrm{pr}_{2} \ldots+\mathrm{pr}_{\mathrm{n}}$

$(\mathrm{RI}=$ Renkonen index; pr $[\%]=$ minor common values for prevalences or relative frequencies [one] of two compared host species regarding infestations by parasite species 1 to "n")

The Jaccard-Index [\%] was employed in order to compare mutual parasite species (Streit, 1980):

$$
\mathrm{J}=\frac{\mathrm{p}_{\mathrm{hc}} \cdot 100}{\mathrm{p}_{\mathrm{h} 1.2}}
$$

$\left(\mathrm{P}_{\mathrm{hc}}=\right.$ number of common parasite species of two compared host species; $\mathrm{P}_{\mathrm{h} 1,2}=$ number of all parasite species of two compared host species)

\section{RESULTS}

\section{Length and food of hosts}

Most sprat and lesser sand eel were one year old, the former ranging from 90 to $120 \mathrm{~mm}$, the latter from 145 to $175 \mathrm{~mm}$ in length. Both species preferred calanoid copepods and cypris larvae (Balanoidea) as food items (Table 1). In contrast, greater sand eel (mostly between 215 and $230 \mathrm{~mm}$ long) fed mainly on lesser sand eels and to a lesser extent on polychaetes and copepods. Sand gobies (mainly 0 - and I-group) were predominantly between 50 and $80 \mathrm{~mm}$ long and fed preferably on Crangon crangon (Linnaeus, 1758) and gammarids.

\section{Parasite burden of hosts}

In total, 9433 parasites were detected in 22 different species or higher taxa. The highest mean burden of 88 parasites per host was found in lesser sand eel. Gobies carried by far the lowest burden, i.e. 0.7 parasites per specimen (Table 2). The infestation rate was $100 \%$ in lesser sand eel, $87 \%$ in sprat, $70 \%$ in greater sand eel, and $25 \%$ in goby. Most fish were infested with several parasite species (Fig. 2), in particular sprat and lesser sand eel; more than $50 \%$ of the latter two species carried 2 to 6 parasite species per host. In gobies, less than $1 \%$ of the specimens contained more than 2 parasite species. The full taxonomy of the following species is given in Table 3.

Highest prevalences among Digenea were achieved by Brachyphallus crenatus and Cryptocotyle lingua in Ammodytes tobianus (Table 3). Brachyphallus also occurred in the other 3 fish species in relatively high prevalences. It was, however, most abundant in Ammodytes, with densities of more than 84 parasites per host (Table 4). Other hemiuroids like Hemiurus communis and Hemiurus luehei were more prevalent in Ammodytes than in other hosts, but in the other fish species they were not as frequent as Brachyphallus. 
Table 1. Percent frequency of occurrence of different food items in sprat Sprattus sprattus (S. spr), lesser sand eel Ammodytes tobianus (A. tob.), greater sand eel Hyperoplus lanceolatus (H. lan.), and sand goby Pomatoschistus minutus (P. min.)

\begin{tabular}{|c|c|c|c|c|}
\hline Number of specimens & $\begin{array}{l}\text { S. spr. } \\
159\end{array}$ & $\begin{array}{c}\text { A. tob. } \\
54\end{array}$ & $\begin{array}{l}\text { H. lan. } \\
39\end{array}$ & $\begin{array}{l}\text { P. min } \\
194\end{array}$ \\
\hline \multicolumn{5}{|l|}{ CRUSTACEA } \\
\hline Crangon & & 8.3 & & 68.3 \\
\hline Gammarids & & 6.7 & & 39.0 \\
\hline Mysids & 17.1 & & & 8.3 \\
\hline Copepods & 73.4 & 91.7 & 12.5 & \\
\hline Balanids & & & & 11.8 \\
\hline Cypris larvae & 37.7 & 53.3 & 2.1 & 27.7 \\
\hline Nauplius larvae & 11.5 & 13.7 & & \\
\hline \multicolumn{5}{|l|}{ POLYCHAETA } \\
\hline Several species & 4.5 & & 14.2 & 14.4 \\
\hline Larvae (plankton) & & 30.0 & & \\
\hline \multicolumn{5}{|l|}{ MOLLUSCA } \\
\hline Hydrobia & & & & 5.8 \\
\hline \multicolumn{5}{|l|}{ TELEOSTEI } \\
\hline Sand eels & & & 46.0 & \\
\hline Gobies & & & 1.7 & 4.4 \\
\hline OTHERS & 2.1 & 5.2 & 9.7 & 5.7 \\
\hline
\end{tabular}

Table 2. Parasitic burden and ecological indices of the helminth communities of sprat ( $S$. spr.), lesser sand eel (A. tob.), greater sand eel (H. lan.), and sand goby $(P$. min.). Hs = diversity index; $E=$ evenness

\begin{tabular}{|lcccc|}
\hline & S. spr. & A. tob. & H. lan. & P. min. \\
\hline Number of examined hosts & 159 & 54 & 39 & 194 \\
Infested by parasites [\%] & 87 & 100 & 70 & 25 \\
Parasitic burden & 26.9 & 87.7 & 7.0 & 0.7 \\
Number of helminth species & 13 & 7 & 6 & 13 \\
Hs (helminth on ly) & 0.95 & 0.20 & 1.32 & 2.03 \\
E (helminth only) & 0.37 & 0.10 & 0.74 & 0.79 \\
\hline
\end{tabular}

Cryptocotyle lingua had higher infestation rates in sand eel than in sprat, but densities were greater in the latter (Tables 3 and 4). In one extreme case, 629 metacercariae were found in a single fish. Very high prevalences and densities were determined for the nematode Hysterothylacium sp., particularly in sprat. In gobies and greater sand eels this nematode showed the highest prevalence of all parasites, although densities were lower than in sprat.

Remarkably high prevalences were found for the parasitic copepods Lernaeenicus sprattae and $L$. encrasicoli in sprat. Almost one-fifth of the investigated sprat were infested (Table 3).

The findings concerning Microphallus primas and the two tetraphyllids deserve 


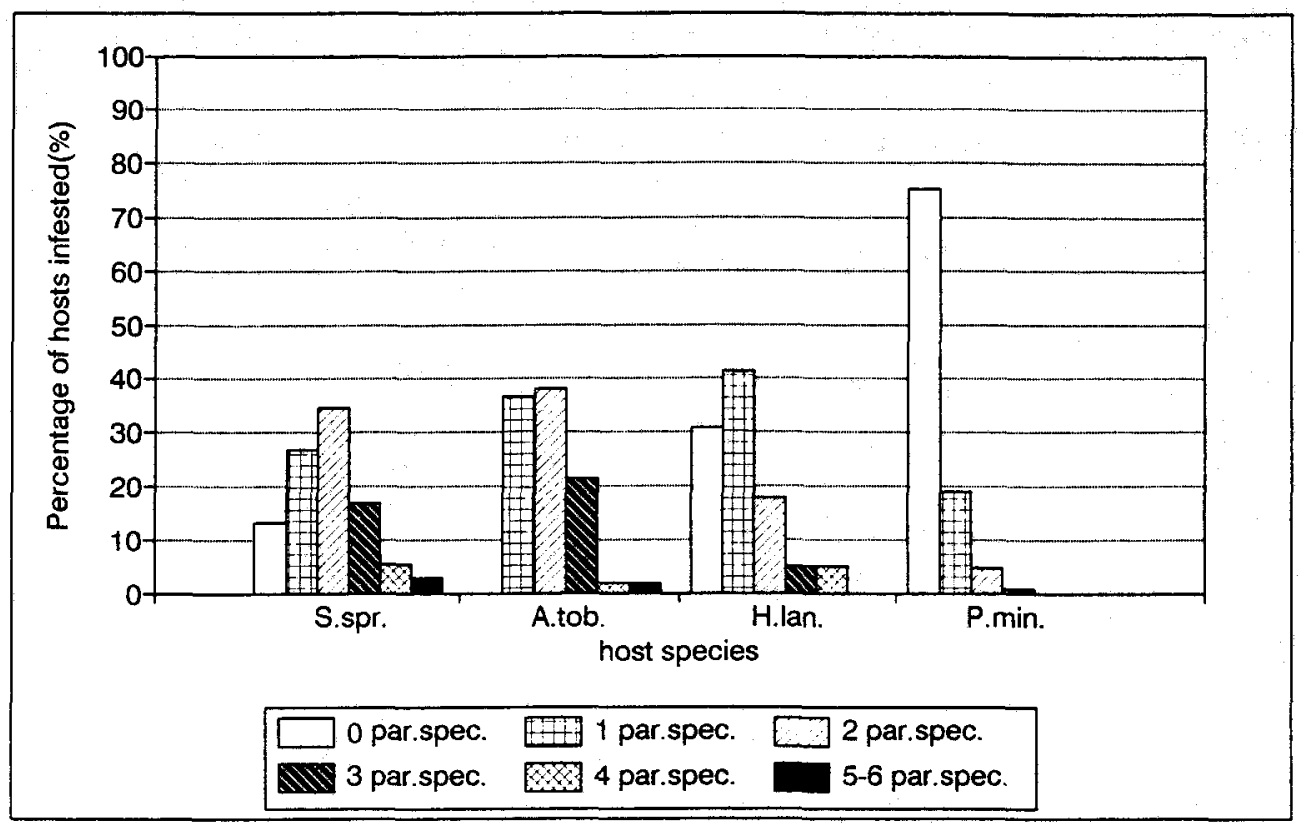

Fig. 2. Prevalences of parasite species (par. spec.) occurring in sprat Sprattus sprattus (S. spr.), lesser sand eel Ammodytes tobianus (A. tob.), greater sand eel Hyperoplus lanceolatus (H. lan.), and sand goby Pomatoschistus minutus (P. min.)

special attention. Generally, metacercariae of microphallids can be found in crustaceans. In this study, cysts as well as free metacercariae were observed in the gut of gobies. Two types of tetraphyllids were present which were referred to as Scolex pleuronectis "type $\mathrm{a}$ " and "type b". "Type a" larvae are about $140 \mu \mathrm{m}$ long with 4 bothrids $(20-25 \mu \mathrm{m})$ which centre around a suction disk. "Type $b$ " is characterized by $175-\mu \mathrm{m}$ long larvae with inverted scolices.

\section{Structure of the helminth community}

The role of the different parasites within the population of their hosts can be described by the abundance (Table 4) in combination with the diversity index and evenness. Ectoparasitic copepods are excluded from the following considerations. The parasite community of sprat consists of 13 helminth species and is unbalanced, as indicated by both low diversity and low evenness. Cryptocotyle lingua and Hysterothylacium sp. were dominant, whereas all other parasites only occurred in low densities. Seven species (5 Digenea and 2 nematodes) were detected in lesser sand eel. Low diversity and low evenness pointed to a one-sided species composition. Brachyphallus crenatus was extremely abundant and thereby far dominant. With regard to prevalence, parasites like Cryptocotyle, Hemiurus sp. and Hysterothylacium were important as well. However, they occurred in much lower densities (Tables 3 and 4). Cryptocotyle, Brachyphallus and Hysterothylacium also dominated the more balanced parasite community of greater sand eels ( 7 helminth spp.), in which only two other Digenea and 
Table 3. Prevalence [\%] and developmental stage of parasites in sprat (S. spr.), lesser sand eel (A. tob.), greater sand eel (H. lan.), and sand goby (P. min.). Cyst = metacercarie encysted; f. metacer. $=$ free metacercarie, not encysted; L3, L4 = 3rd and 4th larval stage; pleroc. = plerocercoid

\begin{tabular}{|c|c|c|c|c|c|}
\hline & S. spr. & A. tob. & H. lanc. & P. min. & Stage \\
\hline \multicolumn{6}{|l|}{ DIGENEA } \\
\hline $\begin{array}{l}\text { Brachyphallus crenatus } \\
\text { (Rudolphi, 1802) }\end{array}$ & 6.9 & 96.3 & 20.5 & 0.5 & adult \\
\hline $\begin{array}{l}\text { Hemiurus communis } \\
\text { Odhner, } 1905\end{array}$ & 8.8 & 22.2 & 10.3 & 0.5 & adult \\
\hline $\begin{array}{l}\text { Hemiurus luehei } \\
\text { Odhner, } 1905\end{array}$ & 5.6 & 20.4 & & & adult \\
\hline $\begin{array}{l}\text { Derogenes varicus } \\
\text { (Müller, 1784) }\end{array}$ & 1.9 & 3.7 & & 2.1 & adult \\
\hline $\begin{array}{l}\text { Lecithaster gibbosus } \\
\text { (Rudolphi, 1802) }\end{array}$ & 3.1 & & & 2.6 & adult \\
\hline $\begin{array}{l}\text { Cryptocotyle lingua } \\
\text { (Creplin, 1825) }\end{array}$ & 23.3 & 35.2 & 28.2 & & cyst \\
\hline $\begin{array}{l}\text { Podocotyle atomon } \\
\text { (Rudolphi, 1802) }\end{array}$ & & & & 0.5 & adult \\
\hline $\begin{array}{l}\text { Pronomrymna ventricosa } \\
\text { (Rudolphi, 1819) }\end{array}$ & 6.9 & & & & adult \\
\hline $\begin{array}{l}\text { Steringotrema pagelli } \\
\quad \text { (Van Beneden, 1871) }\end{array}$ & & & & 0.5 & adult \\
\hline $\begin{array}{l}\text { Microphallus primas } \\
\text { (Jägerskjöld, 1908) }\end{array}$ & & & & 1.0 & f. metacer. \\
\hline \multicolumn{6}{|l|}{ MONOGENEA } \\
\hline $\begin{array}{l}\text { Mazocraes sp. } \\
\quad \text { (Van Beneden, 1870) }\end{array}$ & 0.6 & & & & adult \\
\hline \multicolumn{6}{|l|}{ EUCESTODA } \\
\hline $\begin{array}{l}\text { Bothriocephalus scorpii } \\
\text { (Müller, 1776) }\end{array}$ & & & & 5.2 & pleroc. \\
\hline $\begin{array}{l}\text { Scolex pleuronectis "a" } \\
\quad \text { Müller, } 1788\end{array}$ & 3.1 & & 7.7 & & pleroc. \\
\hline Scolex pleuronectis "b" & 5.0 & & & & pleroc. \\
\hline \multicolumn{6}{|l|}{ NEMATODA } \\
\hline Hysterothylacium sp. & 73.0 & 9.3 & 41.0 & 8.8 & L3, L4 \\
\hline Contracaecum sp. & 6.3 & 5.6 & & 0.5 & $\mathrm{~L} 3, \mathrm{~L} 4$ \\
\hline $\begin{array}{l}\text { Cucullanus heterochrous } \\
\text { Rudolphi, } 1802\end{array}$ & & & & 3.6 & adult \\
\hline $\begin{array}{l}\text { Cucullanus minutus } \\
\text { (Rudolphi, 1819) }\end{array}$ & & & & 0.5 & adult \\
\hline $\begin{array}{l}\text { Cosmocephalus obvelatus } \\
\text { (Creplin, 1825) }\end{array}$ & 2.5 & & 5.2 & 0.5 & L3 \\
\hline $\begin{array}{l}\text { PARASITIC COPEPODA } \\
\text { Lernaeenicus sprattae } \\
\text { (Sowerby, 1804) }\end{array}$ & 18.9 & & & & adult \\
\hline $\begin{array}{l}\text { Lernaeenicus encrasicoli } \\
\text { (Turton, 1807) }\end{array}$ & 18.9 & & & & adult \\
\hline $\begin{array}{l}\text { Lernaeocera minuta } \\
\text { (T. Scott, } 1900 \text { ) }\end{array}$ & & & & 3.6 & adult \\
\hline
\end{tabular}


Table 4. Abundances of parasites and preferred target organ (microhabitat) in the four fish species. See legend to Table 3

\begin{tabular}{|c|c|c|c|c|c|}
\hline & S. spr. & A. tob. & H. lanc. & P. min. & Preferred organ \\
\hline \multicolumn{6}{|l|}{ DIGENEA } \\
\hline Brachyphallus crenatus & 0.15 & 84.48 & 2.44 & 0.01 & stomach \\
\hline Hemiurus communis & 0.13 & 1.20 & 0.28 & 0.01 & stomach \\
\hline Hemiurus luehei & 0.12 & 0.17 & & & stomach \\
\hline Derogenes varicus & 0.04 & 0.11 & & 0.03 & stomach \\
\hline Lecithaster gibbosus & 0.05 & & & 0.03 & intestines \\
\hline Cryptocotyle lingua & 12.68 & 1.44 & 2.67 & & skin \\
\hline Podocotyle atomon & & & & 0.01 & intestines \\
\hline Pronomrymna ventricosa & 0.41 & & & & pyl. caecae \\
\hline Steringotrema pagelli & & & & 0.20 & intestines \\
\hline Microphallus primas & & & & 0.13 & stom., intest. \\
\hline \multicolumn{6}{|l|}{ MONOGENEA } \\
\hline Mazocraes sp. & 0.01 & & & & gill \\
\hline \multicolumn{6}{|l|}{ EUCESTODA } \\
\hline Bothriocephalus scorpii & & & & 0.08 & stomach \\
\hline Scolex pleuronectis "a" & $<0.01$ & & 0.02 & & stom., intest. \\
\hline Scolex pleuronectis " $\mathrm{b}$ " & 0.01 & & & & int., pylorus \\
\hline \multicolumn{6}{|l|}{ NEMATODA } \\
\hline Hysterothylacium sp. & 12.40 & 0.22 & 1.46 & 0.10 & body cavity \\
\hline Contracaecum sp. & 0.18 & 0.06 & & 0.01 & body cavity \\
\hline Cucullanus heterochrous & & & & 0.04 & intestines \\
\hline Cucullanus minutus & & & & 0.03 & stomach \\
\hline Cosmocephalus obvelatus & 0.04 & & 0.05 & 0.01 & body cavity \\
\hline \multicolumn{6}{|l|}{ PARASITIC COPEPODA. } \\
\hline Lernaeenicus sprattae & 0.29 & & & & eye \\
\hline Lernaeenicus encrasicoli & 0.30 & & & & body muscle \\
\hline Lernaeocera minuta & & & & 0.05 & gill \\
\hline
\end{tabular}

Cosmocephalus obvelatus were members. In contrast, the helminth fauna of sand gobies was most diverse, consisting of 13 species. Its parasite community can be regarded as balanced, since it had the highest evenness among the four fish species studied (Table 2). Although Digenea, like Steringotrema pagelli and Microphallus primas, were not important with regard to prevalence (Table 3), they were most abundant followed by Hysterothylacium and Bothriocephalus scorpii (Table 4).

\section{Species composition of the parasites in the four host species}

The greatest degree of conformity in parasite species composition (Fig. 3) and in prevalences was between sprat and the two species of sand eel. The similarity in relative abundance of the helminth species was greatest between sprat and greater sand eel as well as between the two sand eel species. It was lowest between sand eels and gobies. Striking differences were noted in various combinations of hosts, between sprat and sand eels, for example, and between sand goby and the other 3 hosts. 


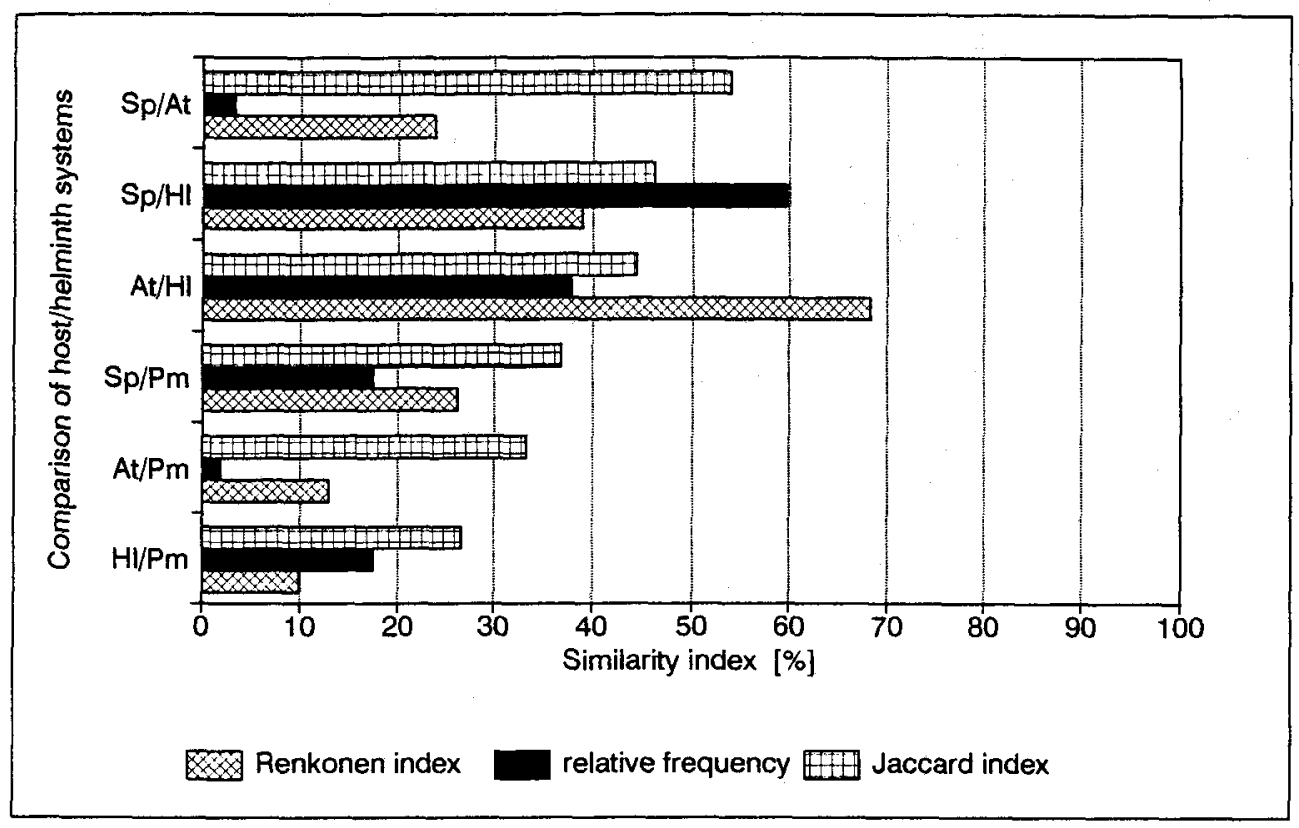

Fig. 3. Comparison of the parasite fauna of the 4 hosts. $\mathrm{Sp}=$ helminth fauna of Sprattus sprattus; At $=$ do. of Ammodytes tobianus, $\mathrm{Hl}=$ do. of Hyperoplus lanceolatus; $\mathrm{Pm}=$ do. of Pomatoschistus minutus

Potential of medium- and small-sized fish to act as transmitters of parasites

Infested fish specimens were grouped according to their potential to act as intermediate or transport hosts for final hosts (Fig. 4) as follows:

(1) Final host for parasites: hosts infested with adult, fertile parasites (cf. Table 3).

(2) Intermediate host: all hosts infested with larval stages of parasites using the host as intermediate host in their life-history.

(2a) Infectious for seabirds or sea mammals: Cryptocotyle lingua, Microphallus primas, Contracaecum sp., Cosmocephalus obvelatus (so-called "allogenous parasites").

(2b) Infectious for predatory fish: Bothriocephalus scorpii, Scolex pleuronectis (two different types), Hysterothylacium sp.

Among the 22 parasite species and higher taxa, 8 species and almost $50 \%$ of all parasite specimens occurred as larvae or juveniles. Three quarters of the sprat were found to be serving as intermediate hosts for different parasites; of these parasites almost one-third were potentially infectious for birds and mammals (Fig. 4). Sand eel carried a considerable portion of intermediate stages of bird parasites. In lesser sand eel, this fraction amounted to $40 \%$. Gobies played only a minor role as intermediate hosts. Only $2 \%$ were potential transmitters of bird parasites. 


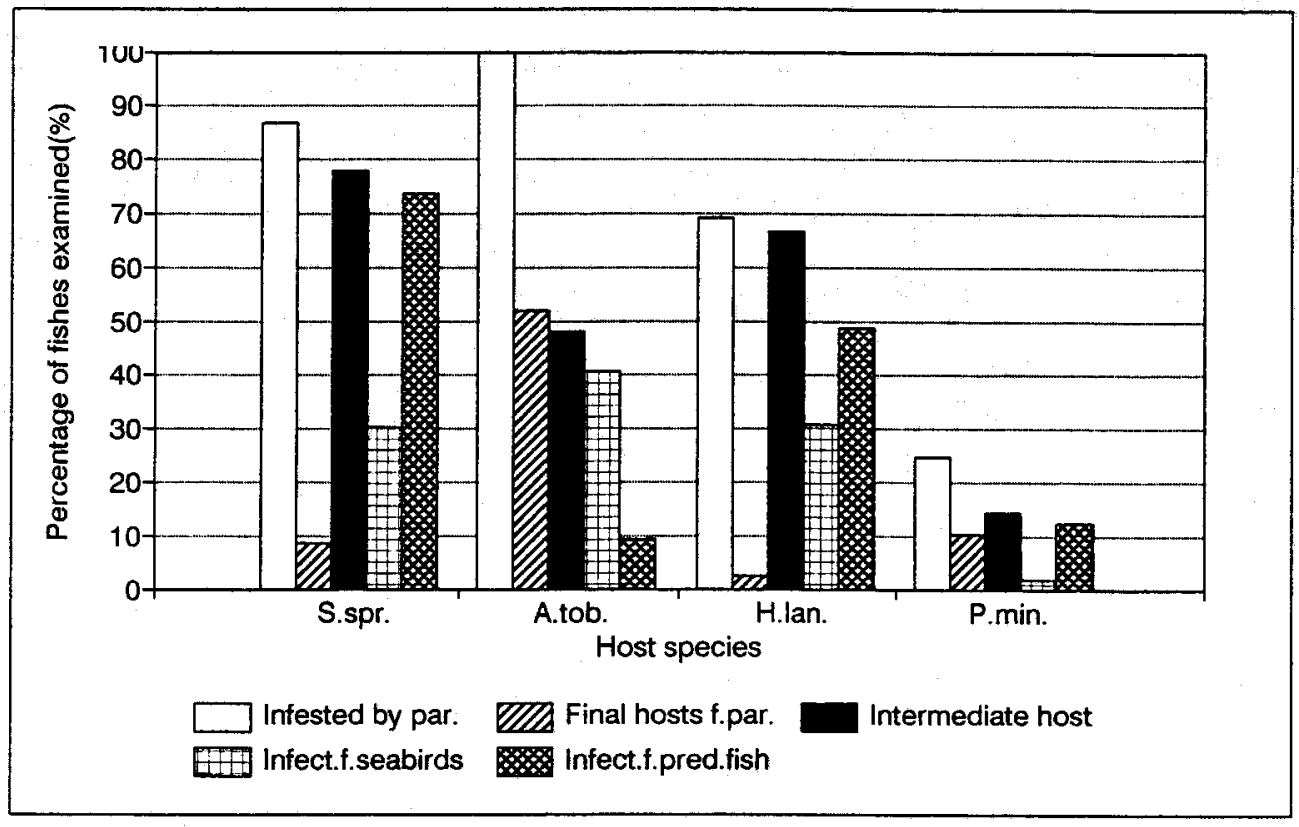

Fig. 4. Potential fraction of the 4 fish species which can act as intermediate or transport hosts for infestation of final hosts. S. spr. = Sprattus sprattus; A. tob. = Ammodytes tobianus; H.lan. = Hyperoplus lanceolatus; $P$. min. = Pomatoschistus minutus

\section{DISCUSSION}

\section{Spectrum of parasite species}

Among the Digenea, the cosmopolitan Hemiurata were dominant. This group is indicative of the feeding habits of the corresponding fish (Reimer, 1970), as the second intermediate hosts are mostly planktonic copepods. This might explain the higher infestation with Brachyphallus crenatus and Hemiurus communis in lesser sand eel which prefer planktonic copepods as food items. Lecithaster gibbosus and Derogenes varicus appeared in sprat, lesser sand eel and sand goby in relatively low densities (Table 4). Køie $(1979,1989)$ has identified many hosts for these parasites in a number of marine areas. The occurrence of a parasite may depend on various factors such as density, food quality and migration patterns of the host (Esch et al., 1989). The presumable primary hosts of Derogenes and Lecithaster, the snails Natica sp. and Odostomia sp., are not at all common in the Wadden Sea (Wolff \& Dankers, 1981) in contrast to Littorina spp., which are the primary hosts of Cryptocotyle lingua and Podocotyle atomon. The silty areas of the highly dynamic Wadden Sea can be considered less suitable for $P$. atomon, since its cercariae move like inchworms on the bottom (Reimer, 1970). In any case, the infestation rates in sand gobies are extremely low compared to those recorded in other studies. Zander et al. (1993) found infestation rates in the Baltic Sea close to $30 \%$. Werding (1969) detected only low numbers of larval $P$. atomon in Littorina littorea. Littorina saxatilis is 
known to be the main primary host of this trematode in the southern North Sea (Gibson \& Bray, 1979). L. saxatilis is common on hard bottoms in the upper intertidal. The crawling cercariae are well-adapted to these conditions (James, 1971). L. saxatilis as well as $L$. littorea can act as first intermediate host for Cryptocotyle lingua and are highly infested in some places, according to Werding (1969) and Lauckner (1984). From spring to autumn, masses of cercariae are released, driven by temperature and other factors (Sindermann \& Farrin, 1962). The cercariae of Cryptocotyle are distinctly positively phototactic (Chapman, 1974). Thus, the lower densities in sand eel as compared to sprat might be related to the nocturnal activity of sand eel. Infestation rates with this sort of metacercariae may also be linked to fish migrations, as pointed out by Gorman \& Moring (1982) for gunell (Pholis gunellus) along rocky sea shores. Perhaps this is the reason for the absence of Cryptocotyle in gobies in this study, since sand gobies most likely inhabit deeper waters at the border of the Wadden Sea in early summer (Fonds, 1973), while the other species were infested in the Wadden Sea proper (Groenewold, 1992). Furthermore, C. lingua has a preference for pelagic fish (Sinderman \& Farrin, 1962). The main hosts of Steringotrema pagelli in the North Sea are dab (Limanda limanda) and lemon sole (Microstomus kitt) according to Køie (1980). Steringotrema pagelli has also been shown to occur in plaice (Pleuronectes platessa) in the southern North Sea (under the synonym: Steringotrema cluthense; Odhner, 1911). Gobies are not mentioned as hosts. The finding in this study was either accidental or related to the benthic behaviour of sand gobies, which this species has in common with the other hosts mentioned above. First intermediate hosts of Steringotrema pagelli are the bivalves Nucula nitidosa and $N$. nucleus which dominate the subtidal bottom in some areas of the North Sea (Salzwedel et al., 1985). It is not clear whether a second intermediate host is involved (Køie, 1980). The life cycle of Pronoprymna ventricosa is completely unknown. This Digenea has been found in the pyloric appendices and in the midgut of clupeids (Bray \& Gibson, 1980), which was also supported by this study. Much information concerning hosts of the two fellostomid species has been compiled from warmer regions (Bray \& Gibson, 1980). In the Mediterranean Sea, Steringotrema pagelli has often been detected in Atherina sp. The distribution centre of Pronoprymna ventricosa is the Mediterranean Sea (in Engraulis sp.), the Black Sea, the Sea of Asov and also the Red Sea. At higher latitudes hosts were sprat, alice shad (Alosa alosa) and twaite shad (A. fallax) along the Belgium coast and in the Irish Sea.

Microphallus primas uses additional paratenic hosts. The second intermediate host of this microphallid are shore crabs (Carcinus maenas) or gammarids such as Gammarus salinus and G. locusta. However, free metacercariae of Microphallus primas and another microphallid - Maritrema subdolum - have also been found in the gut of Pholis gunellus (Reimer, 1963). This pathway offers the opportunity for the parasite to infest birds which feed exclusively on fish. It remains an open question whether infestations of sand gobies, as detected in this study, can be considered an exception or the rule. The life cycle of Microphallus primas was retraced in the laboratory by Saville \& Irwin (1991) employing in ovo cultivation. The main primary is Hydrobia ulvae, which occurs in the Wadden Sea in masses and is the first intermediate host for other microphallids, as well.

An extended life cycle is also known for the nematode Cosmocephalus obvelatus. As in microphallids, no further development takes place in the fish. However, adaptation of Cosmocephalus is much more advanced, since the nematode actively invades the coelom of its transport host (Plötz, 1982a). 
Differently developed stages of plerocercoids of the eucestode Bothriocephalus scorpii have been reported. According to Markowski (1935b), who elucidated the life cycle, Myoxocephalus scorpius besides Scophthalmus maximus is an important final host. The "father lasher" is widely distributed in the Wadden Sea (Dankers \& De Veen, 1978).

The tetraphyllid larvae, which have been referred to as Scolex pleuronectis in this study, have been described for many fish species. They occur mainly and most abundantly in clupeids (Reimer, 1970). Sand eels are not mentioned in the list presented by Williams (1968). However, the findings in greater sand eel reported here cannot be considered unusual, since copepods are common intermediate hosts. Final hosts for all tetraphyllids are elasmobranchs. In the Wadden Sea proper, the most likely target species would be Raja clavata. This species, however, has become extremely rare in this area (Berghahn, 1990).

No species identification was possible for the frequently found specimens of $\mathrm{Hys}$ terothylacium sp. The genus Hysterothylacium has a world-wide distribution and is one of the most abundant nematodes in fish (Möller \& Anders, 1986). In particular, 3 species have been described most frequently (Berland, 1961), which, however, could have been confused with one another (Soleim \& Berland, 1983): Hysterothylacium aduncum, H. gadi and $H$. auctum.

Contracaecum sp. could also not be determined to the species level, which would have revealed the final host. Contracaecum osculatum, for example, is a cosmopolitan nematode of diverse seals (Pinnipedia), (Valtonen et al., 1988; Fagerholm, 1989). The larval stages have been identified with the help of in vitro cultivation (McClelland \& Ronald, 1974), but the life cycle remains unclear. Diverse copepod species (Tisbe furcata, Amphiascus similis) were experimentally infested (Davey, 1969). Fagerhom (1988) clarified the identity of Contracaecum osculatum larvae in cod (Gadus morhua), which is heavily infested with this parasite in the Baltic. Descriptions of the larval stages of Contracaecum species, which have birds as final hosts, were provided by Huizinga (1966) and Deardorff \& Overstreet (1980). The life cycle of Contracaecum spiculigerum (syn.: C. rudolphi) was clarified by Huizinga. Along the west coast of North America, Myoxocephalus octodecimspinosus and Pseudopleuronectes americanus are intermediate hosts (Deardorff \& Overstreet, 1980). Another marine species is Contracaecum variegatum, the larvae of which have not been described (Hartwich, 1975). In conclusion, all 3 species may occur as parasites in the investigated fish species.

Infestation rates of Lerneocera minuta (Tables 3 and 4 ) were close to those reported by Mann (1964), who detected this parasitic copepod in 3-5\% of the gobies from the bycatch of shrimpers. Petersen (1992), however, noted considerable regional differences in prevalence. Apart from Hysterothylacium and Cryptocotyle, Lernaeenicus sprattae and $L$. encrasicoli were the most abundant parasites in sprat $(18.9 \%)$. In the Oslo fjord, Schram (1987) found much lower prevalences: $4.3 \%$ for L. sprattae and only $0.4 \%$ for L. encrasicoli.

\section{Structure of the helminth community}

With respect to dominance, the different helminth species play a variable role within the parasite fauna of the 4 fish species investigated (Table 4). In particular, the very unbalanced helminth community of Ammodytes made it clear that a single species Brachyphallus crenatus - can be completely dominant. According to Hanski (1982), 
Holmes (1989) classifies parasites of a community with regard to their prevalence in core, secondary and satellite species. Core species are characterized by more than $60 \%$ prevalence and a positive correlation between prevalence and density. In this study, only Brachyphallus crenatus in lesser sand eel Ammodytes, and Hysterothylacium sp. in sprat fall into this category (Table 4). Only if seasonal differences in infestation rates are considered, is this also true for Cryptocotyle and H. luehei in Ammodytes (Groenewold, 1992). This result corresponds also to the situation of the goby guild of Lübeck Bight (Zander et al., 1993). Secondary species achieve prevalences between $40 \%$ and $60 \%$, whereas satellite species stay below $40 \%$. It was striking that, besides Brachyphallus, only two species within the community played a major role, all of which had 4 or at least 3 of the fish species as intermediate host, namely Hysterothylacium and Cryptocotyle. Both are not very specific with regard to their second intermediate host (Berland, 1961; Reimer, 1963). Hemiuroids can also be considered to be generalists (Gibson \& Bray, 1979). The highest numbers of Brachyphallus in lesser sand eel may result from accumulation due to selective feeding on planktonic copepods which are the second intermediate hosts. Similar conditions were found for Podocotyle atomon and Hysterothylacium sp. in Zoarces viviparus (Zander, 1991). In contrast, Pronoprymna ventricosa has almost exclusively been detected in other clupeids (Bray \& Gibson, 1980).

The composition of the parasite fauna of different host fishes is highly dependent on the area of the sea (Rohde, 1982). For example, in gobies from brackish waters in the Baltic, typical freshwater parasites were numerous (Markowski, 1935a; Koter, 1962; Zander \& Döring, 1989; Zander et al., 1993). In this study, however, these were not important, since salinity was always above $S=26 \%$. Moreover, Acanthocephala were not present, which were frequently detected in the Baltic Sea (Markowski, 1935a; Zander \& Döring, 1989; Zander et al., 1993), in particular in the Schlei Fjord (Zander \& Westphal, 1991; Kesting, 1992). It should be critically noted that differences in spatial distribution of parasites on a small scale can be considerable as demonstrated by Petersen (1992) for sand goby in the Wadden Sea.

The comparison between the 4 host/helminth systems (Fig.4) provides further information concerning factors which shape the structure of the helminth fauna. The fairly great differences between benthic sand gobies, on the one hand, and sand eels or sprat, on the other, give reason to conclude that the food composition of host fishes and the resulting uptake of intermediate hosts is of paramount importance for the composition and the structure of parasite communities. However, the great similarity between the 2 sand eel species with their quite different food items (Table 1) reveals that other factors are also important. These are, in particular, habitat and behaviour of hosts (activity rhythm, migration) as well as the more difficult to record requirements of parasites concerning their microhabitats.

\section{Importance of small-sized fish as intermediate hosts for parasites}

It is possible that the catchability of fish infested with parasites is increased (Anders \& Möller, 1991). Moreover, infestation with parasites, such as Lernaeenicus in sprat, might make them more accessible to potential predators. However, in view of the role of parasites in small-sized fish from the by-catch of shrimpers, special attention should be paid to the fact that a considerable amount of discards is removed by seabirds or other 
predators (Berghahn \& Rösner, 1992). This aspect has also been stressed by Plötz (1982b), who found high intensities of Cosmocephalus in offal from fisheries around Helgoland Island.

Many investigations have pointed out the important role of smaller-sized fish in the food web. Gobies can contribute more than $20 \%$ (in number) to the food items of seals (Sievers, 1989). Together with sand eel, gobies can represent a considerable share in the food of herring gulls (Larus argentatus), kittywakes (Rissa tridactyla) or other seabirds (Hartwig \& Söhl, 1975; Vauk \& Jokele, 1975; Dornboos, 1984). Goby (Zijlstra, 1978; Zander \& Döring, 1989), sand eel (Reay, 1970), and sprat (Bailey \& Bakken, 1990) are common prey for bigger fishes. Many of these predators are also final hosts for helminth species found in this study. According to Lick (1991), $27 \%$ of the seals in the Wadden Sea are infested with Contracaecum osculatum. In the Kattegat-Skagerrak region, infestation rates were up to $20 \%$ (Lunneryd, 1991). High rates of infestation with Contracaecum variegatum, C. rudolphii and Cosmocephalus obvelatus were detected in herring gull and great black-backed gull (Larus marinus) around Helgoland Island (Plötz, 1979). Sixty-five percent of the herring gulls in the southern North Sea are infested with Cryptocotyle lingua (Loos-Frank, 1971). The infestation rate in nestlings of black-headed gulls (Larus ridibundus) by Microphallus primas, Cosmocephalus, Contracecum variegatum and Cryptocotyle reached 43 to $53 \%$ in prevalence on Wangerooge Island (Lorch et al., 1982).

It remains unclear whether the discards from shrimpers have any effect on the structure of the parasite fauna. Referring to the results of his long-term studies, Lauckner (1990) assumes that the high densities of seabirds (i.e. final hosts) in Königshafen, a small bay on Sylt island, lead to an increase in the density of the corresponding parasites, which consequently affects the species composition and population dynamics of many intermediate hosts. The infestation pressure caused by final hosts may also have an impact on diverse medium and small-sized fish species, e.g. an increase in mortality of fish larvae may be caused by parasites such as Cryptocotyle (Rosenthal, 1967; Lauckner, 1984). In any case, it is evident from the high degree of parasite transmission found in this study how efficiently final hosts might be reached by helminth species via the discards of shrimpers. Berghahn (1990) calculated the potential intake of shrimping discards by herring gulls in the North Frisian Wadden Sea in June (raising of nestlings) as amounting to 17.9 tons.

It should be noted that the conditions for parasites with 2 or 3 hosts in their life cycle are optimal in the Wadden Sea due to the high densities of all intermediate hosts, short infestation pathways and infestation times as well as high encounter rates of intermediate and final hosts. It will be difficult to disentangle these factors from the impact of the shrimp fishery. Even if zero-use areas were provided for comparative studies, the pronounced migratory behaviour of the intermediate hosts, medium and small-sized fish, would most probably mask the potential differences from the fishing grounds.

Acknowledgements. The authors wish to thank the fishermen S. Carstensen and Kalle for their support. This study is supported by the Federal Environmental Agency, Environmental Research Plan of the Minister for the Environment, Nature Conservation and Nuclear Safety of the Federal Republic of Germany (Grant 10802 085/01), and by the state of Schleswig-Holstein. This is publication no. 106 of the project Ecosystem Research Wadden Sea. 


\section{LITERATURE CITED}

Anders, K. \& Möller, H., 1991. Epidemiologische Untersuchungen von Fischkrankheiten im Wattenmeer. - Ber. Inst. Meeresk. Kiel, 207, 1-166.

Bailey, R. S. \& Bakken, E., 1980. Report of the sprat biology workshop, Bergen, 4-7. Nov. 1986. ICES coop. Res. Rep. 169, 1-91.

Berghahn, R., 1990. On the potential impact of shrimping on trophic relationships in the Wadden Sea. In: Trophic relationships in the marine environment. Ed. by M. Barnes \& R. N. Gibson. Aberdeen Univ. Press, Aberdeen, 130-140.

Berghahn, R. \& Rösner, H.-U., 1992. A method to quantify feeding of seabirds on discards from the shrimp fishery in the North Sea. - Neth. J. Sea Res. 28, 347-350.

Berland, B., 1961. Nematodes from some Norwegian marine fishes. - Sarsia 2, 1-50.

Berland, B., 1989. Identification of larval nematodes from fish. In: Nematode problems in North Atlantic fish. Ed. by H. Möller. - C.M./ICES F 6, 16-22.

Bray, R. A. \& Gibson, D. I., 1980. The Fellodistomidae (Digenea) of fishes from the northeast Atlantic. - Bull. Br. Mus. nat. Hist. (Zool.) 37, 199-293.

Chapman, H. D., 1974, The behaviour of the cercaria of Cryptocotyle lingua. - Z. ParasitKde 44, 211-226.

Dankers, N. M. J. A. \& De Veen, J. P., 1978. Variations in relative abundance in a number of fish species in the Wadden Sea and the North Sea costal areas. - Rep. Wadden Sea Working Group 5, 77-105.

Davey, J. T., 1969. The early development of Contracaecum osculatum. - J. Helminthol. 43, $293-298$.

Deardorff, T. L. \& Overstreet, R. M., 1980. Contracaecum multipapillatum (= C. robustum) from fishes and birds in the northern Gulf of Mexiko. - J. Parasit. 66, 853-856.

Doornbos, G., 1984. Piscivorous birds on the saline Lake Grevelingen, the Netherlands: Abundance, prey selection and annual food consumption. - Neth. J. Sea Res. 18, 457-479.

Esch, G. W., Bush, A. O. \& Aho, J. M., 1989. Patterns and processes in helminth parasites communities, an overview. In: Parasites communities: patterns and processes. Ed. by G. W. Esch, A. O. Busch \& J. M. Aho. Chapman \& Hall, London, 1-20.

Fagerholm, H.-P., 1988. Incubation in rats of a nematodal larva from cod to establish its specific identity: Contracaecum osculatum (Rudolphi). - Parasit. Res. 75, 57-63.

Fagerholm, H. P., 1989. Biology of Contracaecum species occurring in fish. - C.M./ICES $F 6,15$.

Fonds, M., 1973. Sand gobies in the Dutch Wadden Sea (Pomatoschistus, Gobiidae, Pisces). - Neth. J. Sea Res. 6, 417-478.

Furness, R. W., 1987. The impact of fisheries on seabird populations in the North Sea. In: Proceedings of the 2nd North Sea Seminar. Werkgroep Nordzee, Amsterdam, 1, 179-192.

Gibson, D. I. \& Bray, R. A., 1979. The Hemiuroidea: terminology, systematics and evolution. - Bull. Br. Mus. nat. Hist. (Zool.) 36, 35-146.

Gorman, A. M. \& Moring, J. R., 1982. Occurrence of Cryptocotyle lingua (Creplin, 1825) (Digenea: Heterophyidae) in the rock gunnel, Pholis gunellus. - Can. J. Zool. 60, 2526-2528.

Groenewold, S., 1992. Zur Bedeutung von Kleinfisch-Parasiten im Nordfriesischen Wattenmeer. Dipl.-Arb., Univ. Hamburg, 98 pp.

Hamerlynck, O., Geets, A. \& Damme, P. van, 1989. The parasites of two sympatric gobies Pomatoschistus minutus and $P$. lozanoi in the Belgian coastal waters. In: Invertebrates of Belgium. Ed. by K. Wouters \& L. Baert. KBIN, Brussels, 27-30.

Hanski, I., 1982. Dynamic of regional distribution: the core and satellite species hypothesis. - Oikos $38,210-221$.

Hartwich, G., 1975. Rhabditida und Ascaridida. - Tierw. Dtl. 62, 1-256.

Hartwig, E. \& Söhl, M., 1975. Zur Nahrung der Silbermöwe (Larus argentatus) auf der Nordseeinsel Sylt. II. Zusammensetzung der Nahrung. - Zool. Anz. 194, 350-360.

Holmes, J. C., 1989. Helminth communities in marine fishes. In: Parasites communities: patterns and processes. Ed. by G. W. Esch, A. O. Bush \& J. M. Aho. Chapman \& Hall, London, 101-130.

Huizinga, H. W., 1966. Studies on the life cycle and development of Contracaecum spiculigerum (Rudolphi, 1809) (Ascarioidea: Heterocheilidae) from marine piscivorous birds. - J. Elisha Mitchell scient. Soc. 82, 181-195. 
James, B. L., 1971. Host selection and ecology of marine digenean larvae. In: ine blology of manne invertebrate larvae. Ed. by D. J. Crisp. University Press, Cambridge, 179-196.

Kesting, V., 1992. Untersuchungen zur Parasitenfauna von Kleinfischen und Schnecken der Ostseeförde Schlei. Dipl.-Arb., Univ. Hamburg, 183 pp.

Køie, M., 1979. On the morphology and life history of Derogenes varicus (Müller, 1784) Looss, 1901 (Trematoda, Hemiuridae). - Z. ParasitKde 59, 67-78.

Køie, M., 1980. On the morphology and life history of Steringotrema pagelli (van Beneden, 1871) Odhner, 1911 and Fellodistomum fellis (Olsson, 1868) Nicoll, 1909 (Syn. S. ovacutum (Lebour, 1908) Yamaguti, 1953 (Trematoda, Fellodistomidae)). - Ophelia 19, 215-236.

Køie, M., 1983. Digenetic trematodes from Limanda limanda (L.) (Osteichtyes, Pleuronectidae) from Danish and adjacent waters, with special reference to their life histories. - Ophelia 22, 201-228.

Køie, M., 1984. Digenetic trematodes from Gadus morhua (Osteichtyes, Gadidae) from Danish and adjacent waters, with special reference to their life histories. - Ophelia 23, 195-222.

Køie, M., 1989. On the morphology and life history of Lecithaster gibbosus (Rudolphi, 1802) Lühe 1901 (Digenea, Hemiuroidea). - Parasit. Res. 75, 361-367.

Koter, M., 1962. Helminth parasites in Gobiidae of the Puck Bay. - Acta parasit. pol. 10, $217-230$.

Kühl, H. \& Kuipers, B., 1978. Qualitative food relationships of Wadden Sea fishes. - Rep. Wadden Sea Working Group 5, 112-123.

Lauckner, G., 1984. The impact of trematode parasitism on the fauna of a North Sea tidal flat. Helgoländer Meeresunters. 37, 185-199.

Lauckner, G., 1990. Parasiten - ihr Einfluß im Ökosystem Wattenmeer. In: Warnsignale aus der Nordsee. Ed. by J. L. Lozán, E. Rachor, B. Watermann \& H. von Westernhagen. Parey, Berlin, 219-230.

Lick, R. R., 1991. Untersuchung zum Entwicklungszyklus (Krebs-Fisch-Säuger) und zur Gefrierresistenz anisakider Nematoden in Nord- und Ostsee. Diss., Univ. Kiel, 195 pp.

Loos-Frank, B., 1971. Zur Trematodenfauna der Silbermöwe (Larus argentatus) an der südlichen Nordsee. - Vogelwarte 26, 202-212.

Lorch, H. J., Schneider, R. \& Loos-Frank, B., 1982. Parasitologische Untersuchungen nestjunger Lachmöwen (Larus ridibundus) in Brutkolonien des Binnenlandes und der Küste. - J. Orn. 123 (1), 29-39.

Lunneryd, S. G., 1991. Anisakid nematodes in the Harbour seal Phoca vitulina from the KattegatSkagerak and the Baltic. - Ophelia 34, 105-115.

Mann, H., 1964. Vorkommen, Verbreitung und Schadwirkung von Lernaeocera minuta T. Scott (Copepoda parasitica). - Veröff. Inst. Meeresforsch. Bremerh. 1, 79-83.

Markowski, S., 1935a. Die parasitischen Würmer von Gobius minutus PALL. des polnischen Baltikums. - Bull. Acad. pol. Sci. (Cl. II; Sér. Sci. biol.) 2, 251-260.

Markowski, S., 1935b. Über den Entwicklungszyklus von Bothriocephalus scorpii (Müller 1776). Bull. Acad. pol. Sci. (Cl. II; Sér. Sci. biol.) 2, 1-17.

McClelland \& Ronald, 1974. In vitro development of the nematode Contracaecum osculatum Rudolphi 1802 (Nematoda: Anisakidae). - Can. J. Zool. 52, 847-855.

Möller, H. \& Anders, K., 1986. Diseases and parasites of marine fishes. Möller, Kiel, 365 pp.

Odhner, T., 1911. Zum natürlichen System der digenen Trematoden. - Zool. Anz. 37, 181-191.

Peterson, F., 1992. Nutritional condition and parasites of the sand goby Pomatoschistus minutus (Pallas) from the German Wadden Sea. - Ophelia 35, 197-207.

Plötz, J., 1979. Zum Vorkommen und zur Bestimmung von Nematoden in Silbermöwe (Larus argentatus) und Mantelmöwe (Larus marinus) von der Insel Helgoland. - Abh. Gebiet Vogelkde $6,139-152$.

Plötz, J., 1982a. Entwicklungsbiologie und Ökologie von Paracuaria tridentata und Cosmocephalus obvelatus (Nematoda, Acuariidae) von Seevögeln. Diss., TU Braunschweig, 118 pp.

Plötz, J., 1982b. Über den Lebenszyklus von Paracuaria tridentata und Cosmocephalus obvelatus (Nematoda, Acuariidae) von Seevögeln. - Seevögel (Sonderbd.) 125-126.

Reay, P. J., 1970. Synopsis of biological data on north atlantic sand eels of the genus Ammodytes (A. tobianus, A. dubius, A. americanus, and A. marinus). - FAO Fish. Synopsis 82.

Reichenow, E., Vogel, H. \& Weyer, F., 1969. Leitfaden zur Untersuchung der tierischen Parasiten des Menschen und der Haustiere. Barth, Leipzig, 418 pp. 
Reimer, L. W., 1963. Zur Verbreitung der Adulti und Larvenstadien der Familie Microphallidae Diana 1924 (Trematoda, Digenea) in der mittleren Ostsee. - Z. ParasitKde 23, 253-273.

Reimer, L. W., 1970. Digene Trematoden und Cestoden der Ostseefische als natürliche Fischmarken. - Parasit. SchrReihe 20, 1-144.

Rohde, K., 1982. Ecology of marine parasites. Univ. of Queensland Press, St Lucia, 245 pp.

Rosenthal, H., 1967. Parasites in larvae of the herring (Clupea harengus L.) fed with wild plankton. Mar. Biol. 1, 10-15.

Salzwedel, H., Rachor, E. \& Gerdes, D., 1985. Benthic macrofauna communities in the German Bight. - Veröff. Inst. Meeresforsch. Bremerh. 20, 199-267.

Saville, D. H. \& Irwin, S. W. B., 1991. In ovo cultivation of Microphallus primas (Trematoda: Microphallidae) metacercariae to ovigerous adults and the establishment of the life cycle in the laboratory. - Parasitology 103, 479-484.

Schram, T., 1987. Prevalence of Lernaeocera sprattae (Sowerby) and L. encrasicoli (Turton) (Copepoda, Pennellidae) infection of sprat from Oslofjord. - Sarsia 72, 279-289.

Sievers, U., 1989. Nahrungsökologische Untersuchungen an Seehunden (Phoca vitulina, Linne 1758) aus dem schleswig-holsteinischen Wattenmeer. - Zool. Anz. 43, 249-260.

Sindermann, C. J. \& Farrin, A. E., 1962. Ecological studies of Cryptocotyle lingua (Trematoda: Heterophyidae) whose larvae cause "pigment spots" in marine fish. - Ecology 43, 69-75.

Soleim, O. \& Berland, B., 1983. The morphology of Thynnascaris adunca (Rudolphi) (Nematoda, Ascaridoidea). - Zool. Scr. 10, 167-182.

Sprehn, C., 1960. Trematoda und Cestoidea. - Tierw. Mitteleur. 1, 361-392.

Streit, B., 1980. Ökologie. Thieme, Stuttgart, 235 pp.

Valtonen, E. T., Fagerholm, H.-P. \& Helle, E., 1988. Contracaecum osculatum (Nematoda: Anisakidae) in fish and seals in Bothnian Bay (northeastern Baltic Sea). - Int. J. Parasit. 18, $365-375$.

Vauk, G. \& Jokele, I., 1975. Vorkommen, Herkunft und Winternahrung Helgoländer Dreizehenmöwen (Rissa trydactyla). - Veröff. Inst. Meeresforsch. Bremerh. 15, 69-77.

Werding, B., 1969. Morphologie, Entwicklung und Ökologie digener Trematodenlarven von Littorina littorea. - Mar. Biol. 3, 306-333.

Williams, H. H., 1968. The taxonomy, ecology and host specificity of some Phyllobothriidae (Cestoda: Tetraphyllidea), a critical revision of Phyllobothrium Beneden, 1849 and comments on some allied genera. - Phil. Trans. R. Soc. 253 (B) 231-307.

Wolff, W. J. \& Dankers, N., 1981. Preliminary checklist of the zoobenthos and nekton species of the Wadden Sea. - Rep. Wadden Sea Working Group 4, 124-132.

Zander, C. D., 1988. Zur Bedeutung von Kleinfischen in Ökosystemen der Ostsee. - Seevögel, 9 , 51-55.

Zander, C. D., 1991. Akkumulation von Helminthen-Parasiten in Aalmuttern - Zoarces viviparus (L.) (Teleostei) der SW Ostsee. - Seevögel 12,70-73.

Zander, C. D. \& Döring, W., 1989. The role of gobies (Gobiidae, Teleostei) in the food web of shallow habitats of the Baltic Sea. In: Proceedings of the 21st European Marine Biology Symposium. Ed. by R. Z. Kłekowski, E. Styczynska-Jurewicz \& L. Fałkowski. Polish Academy of Sciences, Institute of Oceanology, Wrocław, 499-508.

Zander, C. D. \& Westphal, D., 1991. Kleinfischparasiten der Ostseeförde Schlei und ihre Einbindung in die Nahrungskette. - Seevögel 12,4-8.

Zander, C. D., Strohbach, U. \& Groenewold, S., 1993. The importance of gobies (gobiidae, Teleostei) as hosts and transmitters of parasites in the SW Baltic. - Helgoländer Meeresunters. 47, 81-111.

Zijlstra, J. J., 1978. Quantitative aspects of the role of fishes in the Wadden Sea food chains. - Rep. Wadden Sea Working Group 5, 124-132. 